\title{
Cadmium and zinc interaction and phytoremediation potential of seven Salix caprea clones
}

\author{
Sim-Hee Han*, Du-Hyun Kim and Jae Cheon Lee
}

Department of Forest Resources Development, Korea Forest Research Institute, Suwon 441-350, Korea

\begin{abstract}
We evaluated the interaction between $\mathrm{Cd}$ and $\mathrm{Zn}$ in the bioaccumulation of seven clones of Salix caprea, which were exposed both to $\mathrm{Cd}$ and $\mathrm{Zn}$ alone and to a combination of $\mathrm{Cd}$ and $\mathrm{Zn}$. Cadmium (Cd) and $\mathrm{Zn}$ concentration in the four treatments were administered in the following order: root > leaf > stem, and obvious differences were noted among the treatments and clones. The leaf Cd concentration of clone BH2 and stem Cd concentration of clone BH5 in the combined $\mathrm{Cd}$ and $\mathrm{Zn}$ treatment group was increased by $62 \%$ and $110 \%$, respectively, relative of that of the Cd alone treatment group. On the other hand, the leaf and stem Zn concentration of clone BH8 in the combined Cd and Zn treatment group was reduced by $66 \%$ and $61 \%$, respectively, relative to that of the $\mathrm{Zn}$ alone treatment group. Translocation of $\mathrm{Cd}$ and $\mathrm{Zn}$ from the root was higher in the leaf than in the stem, and the combined Cd and $\mathrm{Zn}$ treatment stimulated the translocation of Cd from the root to the leaf and stem, whereas it suppressed the translocation of Zn from the root to the leaf and stem. Therefore, the interaction effects were considered strongly synergistic with $\mathrm{Cd}$ in the presence of $\mathrm{Zn}$, but proved antagonistic to $\mathrm{Zn}$ in the presence of $\mathrm{Cd}$ in the combined $\mathrm{Cd}$ and $\mathrm{Zn}$ treatment group. The phytoremediation potentials of the seven clones, which were estimated from standard indices of $\mathrm{Cd}$ and $\mathrm{Zn}$ concentration in $\mathrm{Cd}$ and $\mathrm{Zn}$ alone and the combined $\mathrm{Cd}$ and $\mathrm{Zn}$ treatment groups, were highest in clone BH3, and lowest in clone BH5. Therefore, we recognize S. caprea as an appropriate material for phytoremediation, and this is particularly the case with clone BH3. However, further research will be required to evaluate the effects of $\mathrm{Cd}$ and $\mathrm{Zn}$ on the physiological changes as well as tolerance mechanisms against metal toxicity in S. caprea clones.
\end{abstract}

Key words: Cd-Zn interaction, phytoremediation potential, Salix caprea, translocation

\section{INTRODUCTION}

Recently, many researchers have attempted to find or develop suitable materials and technology for the remediation of metal-contaminated soils. As a consequence, a number of plants with the ability to accumulate specific heavy metals have been identified, and the biochemical mechanisms relevant to accumulation and defense against heavy metal toxicity have been thoroughly assessed (Tong et al. 2004, Xu et al. 2009). The potential use of trees as a suitable vegetation cover for heavy metalcontaminated land has received an increasing amount of attention over the past 10 years. Trees have been identified as a low-cost, sustainable, and ecologically sound method for the remediation of heavy metal-contaminated land (Dickinson 2000). The use of native plants for phytoremediation is important because these plants are frequently better in terms of survival, growth, and reproduction under environmental stress conditions than plants introduced from other environments.

Willows, an economically important species of tree in Korea, function as potential biomonitors for contami- (cc) This is an Open Access article distributed under the terms of the Creative Commons Attribution Non-Commercial License (http://creativecommons.org/licenses/by-nc/3.0/) which permits unrestricted non-commercial use, distribution, and reproduction in any medium, provided the original work is properly cited.
Received 19 April 2010, Accepted 11 May 2010

${ }^{*}$ Corresponding Author

E-mail: simhee02@forest.go.kr

Tel: +82-31-290-1156 
nated, sediment-derived soils, with foliar samples being employed to evaluate metal bioavailability, as previously described by Vandecasteele et al. (2002, 2005). However, metal concentrations in willows depend heavily on species (Lunácková et al. 2003, Vandecasteele et al. 2004, 2005, Han et al. 2007), clone (Landberg and Greger 2002, Vandecasteele et al. 2005), growth performance (KlangWestin and Perttu 2002), root density and distribution within the soil profile (Keller et al. 2003), and sampling period (Vandecasteele et al. 2004, 2005). Additionally, as willows are relatively easy to grow from cuttings and evidence high growth rates, they are rather well suited both to the testing of metal bioavailability and accumulation, and also to phytoremediation, which can be combined with energy production from biomass (Dimitriou et al. 2006, Lewandowski et al. 2006, Vervaeke et al. 2006, Meers et al. 2007).

In Korea, there are hundreds of closed and abandoned zinc mines, many of which have been contaminated by a variety of toxic metals, such as $\mathrm{Cd}, \mathrm{Zn}, \mathrm{Pb}, \mathrm{Ni}$, As, etc. In particular, $\mathrm{Cd}$ and $\mathrm{Zn}$ concentrations in mining soil have been measured at more than 30 and 2,600 mg/kg, respectively (Ministry of Environment 2009).

Cadmium, which is not essential to plants, and $\mathrm{Zn}$, which is essential to plants, is elements with otherwise similar geochemical and environmental properties (Siedlecka 1995). The association of $\mathrm{Cd}$ and $\mathrm{Zn}$ in the environment and their relative chemical similarity result in interactions between $\mathrm{Cd}$ and $\mathrm{Zn}$ during plant uptake, as well as transport from roots to aboveground parts (Das et al. 1997). Studies undertaken to gain insight into the interaction between $\mathrm{Zn}$ and $\mathrm{Cd}$ have generated inconsistent results. White and Chaney (1980) previously reported that Cd uptake was reduced in both soybean roots and shoots via the application of $\mathrm{Zn}$. Wu and Zhang (2002) previously noted that the physiological damage induced by Cd toxicity might be alleviated by the application of Zn. Eriksson (1990) determined that the Zn-Cd interaction varied with different crop species. Few studies, however, have been conducted thus far regarding the interaction of $\mathrm{Cd}$ and $\mathrm{Zn}$ in tree species grown in high metal-contaminated soil.

The overall objectives of this research were to gain insight into the Cd-Zn interaction in the context of Cd$\mathrm{Zn}$ bioaccumulation of Salix clones in high Cd- and Zncontaminated soil, and to evaluate the feasibility of using these plants for phytoremediation purposes. The results of this study should provide us with information regarding the use of Salix species for the restoration and revegetation of metal-contaminated soils.

\section{MATERIALS AND METHODS}

\section{Plant materials and treatments}

Seven Salix caprea clones were collected from tailing soils of the Yeonwha mining area in Bonghwa, Korea. In a previous study, S. caprea was reported to evidence the highest phytoremediation potential on $\mathrm{Cd}$ and $\mathrm{Zn}$ of five Salix species (Han et al. 2007). The experiment was conducted in a greenhouse from April to September of 2007. Cuttings (approximately $10 \mathrm{~cm}$ length and $1 \mathrm{~cm}$ diameter) were planted in containers $(35 \mathrm{~cm} \mathrm{~W} \times 52 \mathrm{~cm}$ $\mathrm{L} \times 9 \mathrm{~cm} \mathrm{H}$ ) filled with vermiculite in early April. Seven weeks after planting, 20 cuttings (five replicates each for four treatments) of the same height (approximately 10 $\mathrm{cm}$ length and $3 \mathrm{~mm}$ diameter) were transplanted into individual plastic pots (20 cm depth, $17 \mathrm{~cm}$ top diameter) with sand. Cadmium and $\mathrm{Zn}$ were added at the following concentrations: 0 (control), $112 \mathrm{mg} / \mathrm{kg} \mathrm{Cd}, 260 \mathrm{mg} / \mathrm{kg} \mathrm{Zn}$, and $112 \mathrm{mg} / \mathrm{kg} \mathrm{Cd}+260 \mathrm{mg} / \mathrm{kg} \mathrm{Zn}$ as $\mathrm{CdSO}_{4} \cdot 8 / 3 \mathrm{H}_{2} \mathrm{O}$ and $\mathrm{ZnSO}_{4} \cdot 7 \mathrm{H}_{2} \mathrm{O}$ solution. Each solution was adjusted to $\mathrm{pH}$ 6.8 (pH of tap water). The average heavy metal concentrations were $270 \mathrm{mg} / \mathrm{kg}$ As, $112 \mathrm{mg} / \mathrm{kg} \mathrm{Cd}, 72 \mathrm{mg} / \mathrm{kg} \mathrm{Cu}$, $446 \mathrm{mg} / \mathrm{kg} \mathrm{Pb}$ and $260 \mathrm{mg} / \mathrm{kg} \mathrm{Zn}$. The pots were arranged on a bench inside the glasshouse in accordance with a completely randomized design with five replicates. During the growing season, tap water was added daily to maintain soil moisture, and fertilizer solution $(1 / 5,000$ of original solution) was administered at a concentration of $200 \mathrm{~mL}$ once per week. The liquid fertilizer employed was composed of $10 \% \mathrm{TN}, 4 \% \mathrm{P}, 5 \% \mathrm{~K}, 0.05 \% \mathrm{~B}, 0.05 \% \mathrm{Cu}$, and $0.15 \% \mathrm{Mn}$.

After $120 \mathrm{~d}$ of growth, the leaves, stems, and roots were carefully removed, then rinsed thoroughly twice with distilled water. After oven drying of the tissues at $70^{\circ} \mathrm{C}$ to constant weight, the dry weights of the leaves, stems, and roots were recorded.

\section{Cd and $\mathrm{Zn}$ analyses}

The dried leaves, stems, and roots ( $0.5 \mathrm{~g}$ each) were ground $(<1 \mathrm{~mm})$ and used to determine the concentrations of $\mathrm{Cd}$ and $\mathrm{Zn}$. Nitric acid $(70 \%, 15 \mathrm{~mL})$ and hydrogen peroxide $(30 \%, 5 \mathrm{~mL})$ were added to $0.5 \mathrm{~g}$ of dried, ground plant samples in a digestion vessel. The samples were digested using the microwave digestion system, cooled after the addition of distilled water, and filtered prior to analysis. Cadmium and Zn concentration in the digested tissues were measured using an atomic absorption spectrophotometer (AA-6701F; Shimadzu, Tokyo, 
Japan). In order to verify the accuracy of our determinations of $\mathrm{Cd}$ and $\mathrm{Zn}$, standard reference materials of pepperbush (CRM No.1) and sargasso (CRM No.9) provided by the National Institute for Environmental Studies, Tsukuba, Japan were analyzed. The recovery rates of $\mathrm{Cd}$ and $\mathrm{Zn}$ with respect to their certified values were between $90 \%$ and $95 \%$.

Leaf and stem translocation factor (TF), which is defined as the ratio of the concentration of a metal in leaf and stem to its concentration in the root, was used to estimate the plant's potential for use in phytoremediation purposes. The phytoremediation ability of the seven $S a$ lix clones was ranked on the basis of $\mathrm{Cd}$ and $\mathrm{Zn}$ concentrations in $\mathrm{Cd}$ and $\mathrm{Zn}$ alone, as well as in the combined $\mathrm{Cd}$ and $\mathrm{Zn}$ treatment group. The standard index (SI) on each concentration was calculated as $(\mathrm{X}-\mathrm{Xavg}) / \mathrm{SD}$, where $\mathrm{X}$ is the average concentration for the leaf, stem, and root of each clone, Xavg is the average concentration of all clones, and SD is the standard deviation of seven clones. The total sum of the standard index calculated from 4 concentrations was aggregated to evaluate the phytoremediation potential.

\section{Statistical analysis}

The data were statistically analyzed using the SAS ver. 8.01 (SAS Inc., Chicago, IL, USA). Mean values per treatment were compared via GLM. When significant differences $(P=0.05)$ were indicated, Duncan's multiple range tests were conducted.

\section{RESULTS AND DISCUSSION}

\section{Cadmium and zinc concentration}

In our study, we detected significant effects of Cd and $\mathrm{Zn}$ treatment, clones, and their interactions with $\mathrm{Cd}$ and $\mathrm{Zn}$ concentrations and TF $(P<0.05)$. In the $\mathrm{Cd}$ or $\mathrm{Zn}$ alone treatments, $\mathrm{Cd}$ concentrations in the cuttings ranged from $158 \mathrm{mg} / \mathrm{kg}$ in the stem of clone BH5 to as high as $712 \mathrm{mg} / \mathrm{kg}$ in the root of clone BH5 (Fig. 1). Zn concentrations varied from $774 \mathrm{mg} / \mathrm{kg}$ in stem of clone BH5 to $3,234 \mathrm{mg} / \mathrm{kg}$ in the root of clone BH8 (Fig. 2). In the majority of plant samples, the concentrations of $\mathrm{Cd}$ and $\mathrm{Zn}$ in the root were far in excess of those in the leaves and stem, thereby indicating low mobility of $\mathrm{Cd}$ and $\mathrm{Zn}$ from the roots to the shoots and the immobilization of heavy metals in the roots. Although Cd and Zn concentrations in all treatments were in the order, root $>$ leaf $>$ stem, there were obvious differences among the treatments and clones. In particular, the concentration of $\mathrm{Cd}$ in the combined $\mathrm{Cd}$ and $\mathrm{Zn}$ treatment group was completely different from that of $\mathrm{Cd}$ treatment alone. In the combined $\mathrm{Cd}$ and $\mathrm{Zn}$ treatments, Cd concentrations in the stems of clones BH3, 5, 8, and 11 were higher than the $\mathrm{Cd}$ concentrations detected in the leaves (Fig. 1). Additionally, the low mobility of Cd was improved in the combined $\mathrm{Cd}$ and $\mathrm{Zn}$ treatment group. The leaf Cd concentration of clone $\mathrm{BH} 2$ and the stem Cd concentration of clone BH5 in the combined $\mathrm{Cd}$ and $\mathrm{Zn}$ treatment group were increased by $62 \%$ and $110 \%$, respectively, relative to those in the Cd alone treatment group. However, the root
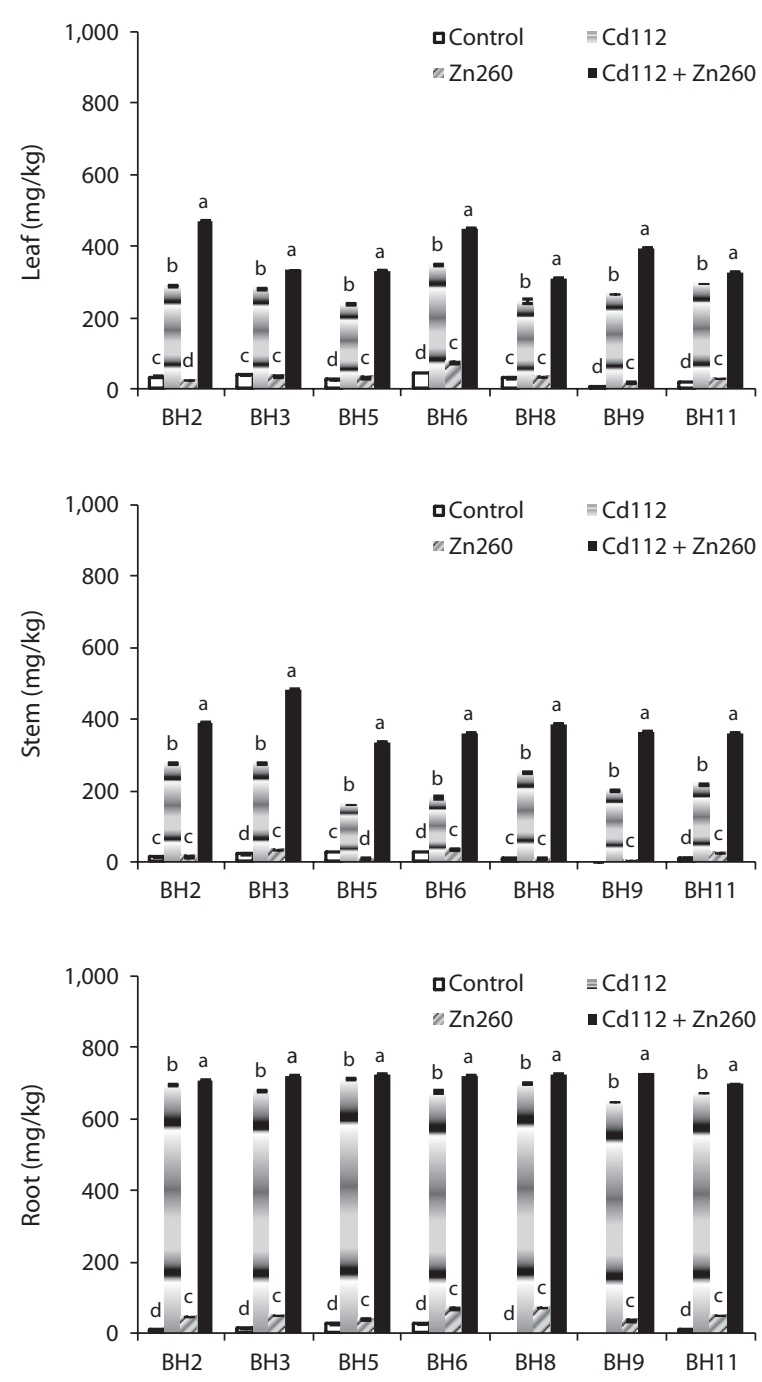

Fig. 1. Cadmium concentration in the leaves, stems, and roots of seven Salix caprea clones treated with $\mathrm{Cd}$ or $\mathrm{Zn}$ alone or a combination of $\mathrm{Cd}$ and $\mathrm{Zn}$. Each bar represents the mean of five replicates \pm standard deviation. Means with different letters are significantly different among treatments at $P<0.05$. 
Cd concentration of all clones in the combined Cd and $\mathrm{Zn}$ treatment group was not significantly different from those of the $\mathrm{Cd}$ alone treatment group.

The low mobility of Zn, unlike that of Cd, was not improved in the combined $\mathrm{Cd}$ and $\mathrm{Zn}$ treatment group. Leaf and stem $\mathrm{Zn}$ concentrations of clone BH8 in the combined $\mathrm{Cd}$ and $\mathrm{Zn}$ treatment group was reduced by $66 \%$ and $61 \%$, respectively, relative to those in the $\mathrm{Zn}$ alone treatment group. Root $\mathrm{Zn}$ concentration of all clones in the combined $\mathrm{Cd}$ and $\mathrm{Zn}$ treatment were also reduced from $3 \%$ to $41 \%$ relative to the $\mathrm{Zn}$ alone treatment group (Fig. 2).

Metal concentrations in plants vary with the plant species (Alloway et al. 1990), and the uptake of heavy metals
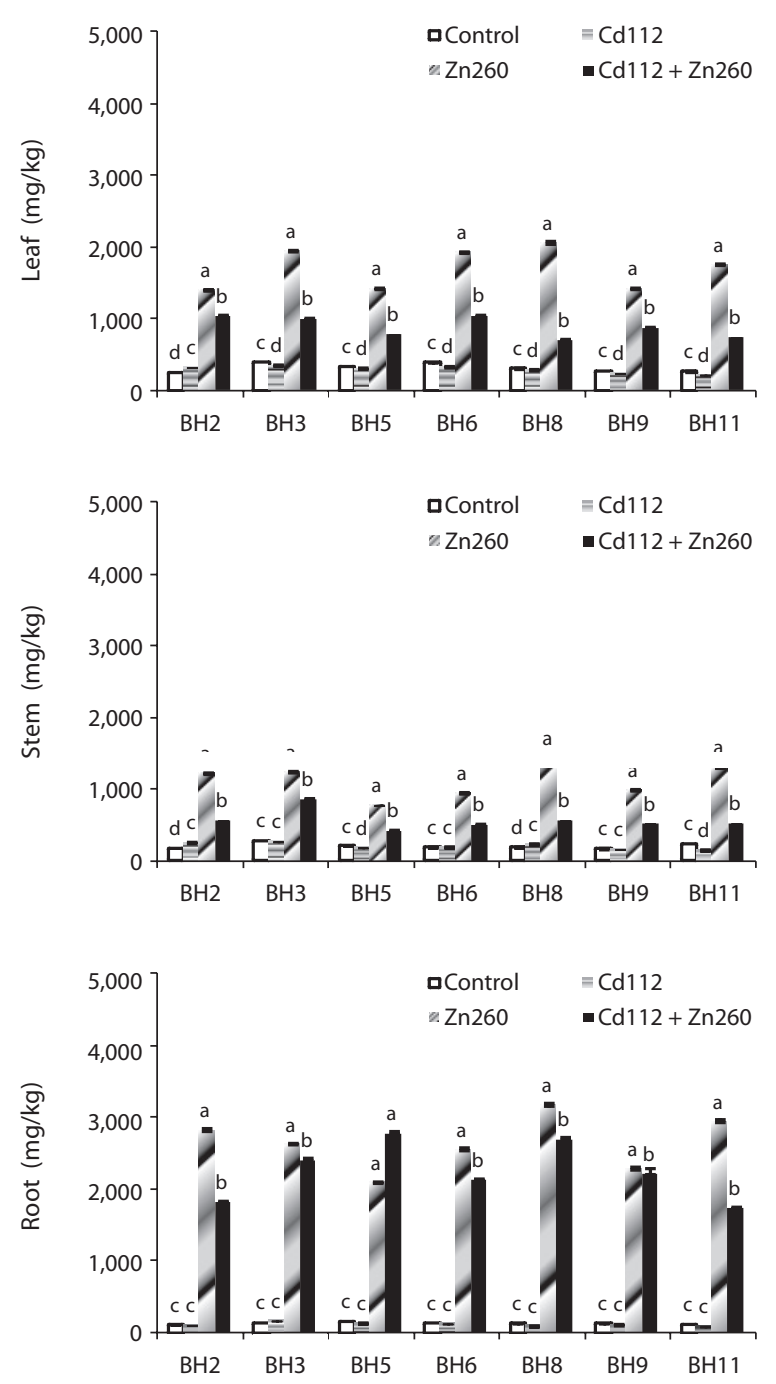

Fig. 2. Zinc concentration in the leaves, stems, and roots of seven Salix caprea clones treated with $\mathrm{Cd}$ or $\mathrm{Zn}$ alone or with combined $\mathrm{Cd}$ and $\mathrm{Zn}$. Each bar represents the mean of five replicates \pm standard deviation. Means with different letters differ significantly among treatments at $P<0.05$. by plants from soil occurs either passively with the mass flow of water into the roots, or via active transport across the plasma membranes of root epidermal cells. Generally, heavy metal uptake by roots depends on both soil and plant factors (e.g. source and chemical form of elements in soil, $\mathrm{pH}$, CEC, organic material, plant species and tissues, plant age, etc.).

The interaction between $\mathrm{Cd}$ and $\mathrm{Zn}$ in plant tissues is known to be remarkably variable, involving species-, population-, and exposure-dependent interactions (Eriksson 1990). For instance, some studies have demonstrated that $\mathrm{Zn}$ (or Cd) suppresses the bioaccumulation of $\mathrm{Cd}$ (or $\mathrm{Zn}$ ) by reducing uptake (i.e., antagonistic interactions) (White and Chaney 1980, Hart et al. 2002), whereas other studies have demonstrated that $\mathrm{Zn}$ (or Cd) enhances the bioaccumulation of $\mathrm{Cd}$ (or $\mathrm{Zn}$ ) by increasing uptake (i.e., synergistic interaction) (Dudka et al. 1994, Xu et al. 2009).

Generally, however, most of our findings may be summed up as follows: $\mathrm{Zn}$ reduces the uptake of Cd by both the root and foliar systems (Adriano 1986). White and Chaney (1980) previously noted that Cd uptake was reduced in both soybean roots and shoots via the application of $\mathrm{Zn}$. In support of these results, Gomes et al. (2002) demonstrated that Cd uptake is mediated via the movement of a $\mathrm{Zn}$-transporter protein across the plasma membrane in yeast cells. Zinc was also shown to interfere with phloem-mediated $\mathrm{Cd}$ transport in durum wheat, possibly by competition with $\mathrm{Cd}$ for the binding sites of a common transporter protein on the plasma membranes of sieve tube cells (Cakmak et al. 2000).

Unlike the results of a previous study (White and Chaney 1980, Adriano 1986, Nan et al. 2002), the interaction effects of $\mathrm{Cd}$ and $\mathrm{Zn}$ in the present work were found to be synergistic with $\mathrm{Cd}$, in the presence of $\mathrm{Zn}$ strongly elevating leaf and stem Cd concentrations, but antagonistic to $\mathrm{Zn}$, in the presence of $\mathrm{Cd}$, which elevates leaf and stem Zn concentrations when exposed to high concentrations of Cd and $\mathrm{Zn}$. Xu et al. (2009) reported that shoot and root $\mathrm{Cd}$ concentrations in the combined $\mathrm{Cd}$ and $\mathrm{Zn}$ treatment group with the addition of EDTA were increased by $18.6 \%$ and $391.9 \%$, respectively, and shoot and root $\mathrm{Cd}$ concentrations were in the following order: $\mathrm{Cd}+\mathrm{Zn}>\mathrm{Cd}>\mathrm{Zn}$, in the presence of EDTA. Huebert and Shay (1992) suggested that the increases in shoot and root Cd concentrations in the combined $\mathrm{Cd}$ and $\mathrm{Zn}$ treatment group in the presence of EDTA may have been attributable to the application of synthetic chelators to contaminated soils, which can enhance the uptake and accumulation of heavy metals in plant shoots, and the 
interaction of $\mathrm{Cd}$ and $\mathrm{Zn}$ on the uptake of $\mathrm{Cd}$ and $\mathrm{Zn}$ by plants is affected by the presence of chelators such as EDTA.

In contrast to the observed increase in Cd concentration, the results of our present study demonstrated that leaf, stem, and root $\mathrm{Zn}$ concentrations were reduced in the combined $\mathrm{Cd}$ and $\mathrm{Zn}$ treatment group. Xu et al. (2009) noted that, after the addition of EDTA, shoot and root Zn concentrations were reduced in the combined $\mathrm{Zn}$ and $\mathrm{Cd}$ treatment group, and $\mathrm{Zn}$ concentrations were in the order of $\mathrm{Zn}>\mathrm{Cd}+\mathrm{Zn}>\mathrm{Cd}$ in both the absence and presence of EDTA. Based on these results, Xu et al. (2009) proposed that the presence of $\mathrm{Cd}$ in soil inhibited the uptake of $\mathrm{Zn}$ by plants.

\section{Translocation factor}

The patterns of cadmium and $\mathrm{Zn}$ of the seven clones are provided in Fig. 3. In the $\mathrm{Cd}$ alone treatment group, the leaf Cd TF ranged from 0.33 (clone BH5) to 0.51 (clone BH6) and the stem Cd TF ranged from 0.22 (clone BH5) to 0.40 (clone BH3) (Fig. 3). In the Zn alone treatment group, leaf Zn TF ranged between 0.48 (clone BH2) and 0.74 (clone BH6), and the stem Zn TF ranged between 0.36 (clone BH5) and 0.46 (clone BH3). Although the TF of $\mathrm{Cd}$ and $\mathrm{Zn}$ from root to leaves was higher than from the roots to the stems, the value was still less than 1 . This implies that the accumulation of $\mathrm{Cd}$ and $\mathrm{Zn}$ in the roots was more profound than in the leaf and stem. In a manner similar to that of the Cd concentration, the combination $\mathrm{Cd}$ and $\mathrm{Zn}$ treatment stimulated the translocation of $\mathrm{Cd}$ from the roots to the leaves and from the roots to the stem, whereas it suppressed the translocation of $\mathrm{Zn}$ from the root to the leaf and stem. Leaf Cd TF in clone $\mathrm{BH} 2$ and stem Cd TF in clone BH5 were increased by $59.4 \%$ and $106.7 \%$, respectively, relative to the $\mathrm{Cd}$ alone treatment group. However, the leaf Zn TF in clone BH9 and the stem $\mathrm{Zn} \mathrm{TF}$ in clone BH5 were reduced by $59.7 \%$ and $58.7 \%$, respectively, relative to the $\mathrm{Zn}$ alone treatment group. Interestingly, however, the leaf $\mathrm{Zn}$ TF in clone $\mathrm{BH} 2$ was increased in the combined $\mathrm{Cd}$ and $\mathrm{Zn}$ treatment group. The observed increase in the leaf $\mathrm{ZnTF}$ in clone BH2 indicated that the reduction in the leaf $\mathrm{Zn}$ concentration (25\%) was lower than that of the root $\mathrm{Zn}$ concentration $(35 \%)$ in the combined $\mathrm{Cd}$ and $\mathrm{Zn}$ treatment group.

The reason for these differences between the previous results (White and Chaney 1980, Adriano 1986, Nan et al. 2002) and those of the present work may be the result of different $\mathrm{Cd}$ and $\mathrm{Zn}$ concentrations and their combinations in soils, as well as the different characteristics of the
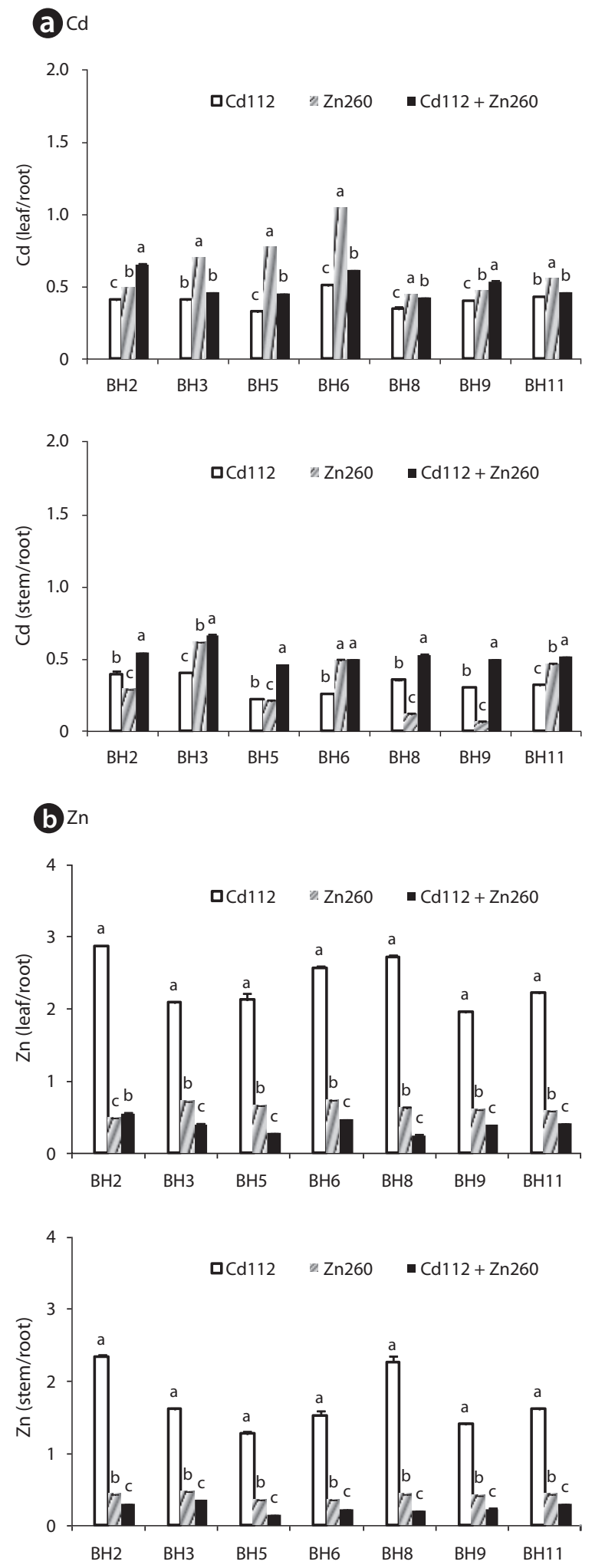

Fig. 3. Translocation factors on $\mathrm{Cd}(\mathrm{a})$ and $\mathrm{Zn}(\mathrm{b})$ from root-to-leaf and from root-to-stem of seven Salix caprea clones treated with $\mathrm{Cd}$ or $\mathrm{Zn}$ alone or with a combination of $\mathrm{Cd}$ and $\mathrm{Zn}$. Each bar represents the mean of five replicates \pm standard deviation. Means with different letters differ significantly among species at $P<0.05$. 
soils and the different plant species and tissues utilized in these studies (Huebert and Shay 1992, Xu et al. 2006).

Therefore, the results of this study indicate that in soils contaminated at high levels with $\mathrm{Cd}$ and $\mathrm{Zn}$, soil $\mathrm{Zn}$ should not be expected to reduce Cd significantly in plant parts, although there a strong antagonistic Zn effect on $\mathrm{Cd}$ accumulation has been noted in plant tissues. Moreover, our findings are generally consistent with those reported by Smilde et al. (1992), Moraghan (1993) and Zhou et al. (1994). Smilde et al. (1992) concluded that $\mathrm{Cd}$ and $\mathrm{Zn}$ were synergistic to some degree, with plant $\mathrm{Zn}$ uptake increasing with the application of $\mathrm{Cd}$ on the basis of interaction experiments conducted in pots filled with loam soil. Moraghan (1993) reported that the Cd-Zn effects were synergistic in the presence of added $\mathrm{Cd}$, and that the accumulation of $\mathrm{Cd}$ in flax seed was reduced by added $\mathrm{Zn}$ in the absence of added Cd. Zhou et al. (1994) concluded from their experiment that the interaction between $\mathrm{Cd}$ and $\mathrm{Zn}$ resulted in an increase in Cd accumulation and a reduction in $\mathrm{Zn}$ uptake in the rice plant.

Based on our results, it would be difficult to select the optimal material for phytoremediation, owing to the complex interaction between $\mathrm{Cd}$ and $\mathrm{Zn}$. Thus, in an effort to select the optimal clone for $\mathrm{Cd}$ and $\mathrm{Zn}$ phytoremediation, the phytoremediation potential of the seven clones studied herein was ranked on the basis of the total sum of standard indices calculated from the $\mathrm{Cd}$ and $\mathrm{Zn}$ concentrations in $\mathrm{Cd}$ and $\mathrm{Zn}$ alone and in the combined $\mathrm{Cd}$ and $\mathrm{Zn}$ treatment group (Table 1). As a consequence, clone BH3 evidenced the most profound (SI = 3.68) phytoremediation potential, and clone BH5 evidenced the lowest $(\mathrm{SI}=$-3.44).

Table 1. Standard indices on $\mathrm{Cd}$ and $\mathrm{Zn}$ concentration of seven Salix caprea clones treated with $\mathrm{Cd}$ or $\mathrm{Zn}$ alone or the combined $\mathrm{Cd}$ and $\mathrm{Zn}$

\begin{tabular}{lccccc}
\hline \multirow{2}{*}{ Clone } & \multicolumn{2}{c}{ Cd concentration } & \multicolumn{2}{c}{ Zn concentration } & \multirow{2}{*}{ Total } \\
\cline { 2 - 5 } & Cd112 & Cd112 + Zn260 & Zn260 & Cd112 + Zn260 & \\
\hline BH5 & $-1.40 \pm 0.10^{\mathrm{d}}$ & $-1.18 \pm 0.13^{\mathrm{e}}$ & $-1.57 \pm 0.07^{\mathrm{f}}$ & $0.71 \pm 0.12^{\mathrm{b}}$ & $-3.44 \pm 0.42^{\mathrm{e}}$ \\
BH9 & $-1.32 \pm 0.07^{\mathrm{d}}$ & $0.18 \pm 0.07^{\mathrm{c}}$ & $-1.04 \pm 0.09^{\mathrm{e}}$ & $-0.25 \pm 0.25^{\mathrm{c}}$ & $-2.43 \pm 0.46^{\mathrm{d}}$ \\
BH11 & $0.01 \pm 0.01^{\mathrm{c}}$ & $-1.24 \pm 0.14^{\mathrm{e}}$ & $0.69 \pm 0.12^{\mathrm{b}}$ & $-1.77 \pm 0.10^{\mathrm{e}}$ & $-2.32 \pm 0.47^{\mathrm{d}}$ \\
BH6 & $0.27 \pm 0.25^{\mathrm{c}}$ & $0.78 \pm 0.15^{\mathrm{b}}$ & $-0.06 \pm 0.10^{\mathrm{d}}$ & $-0.05 \pm 0.13^{\mathrm{c}}$ & $0.93 \pm 0.62^{\mathrm{c}}$ \\
BH8 & $0.16 \pm 0.28^{\mathrm{c}}$ & $-0.75 \pm 0.12^{\mathrm{d}}$ & $1.58 \pm 0.11^{\mathrm{a}}$ & $0.66 \pm 0.11^{\mathrm{b}}$ & $1.65 \pm 0.59^{\mathrm{bc}}$ \\
BH2 & $1.35 \pm 0.35^{\mathrm{a}}$ & $1.33 \pm 0.14^{\mathrm{a}}$ & $-0.03 \pm 0.10^{\mathrm{d}}$ & $-0.71 \pm 0.12^{\mathrm{d}}$ & $1.94 \pm 0.70^{\mathrm{b}}$ \\
BH3 & $0.94 \pm 0.12^{\mathrm{b}}$ & $0.88 \pm 0.08^{\mathrm{b}}$ & $0.44 \pm 0.11^{\mathrm{c}}$ & $1.41 \pm 0.16^{\mathrm{a}}$ & $3.68 \pm 0.46^{\mathrm{a}}$ \\
\hline
\end{tabular}

Each data represents mean of five replicates \pm standard deviation. Means with the different letter in column are significantly different among species at $P<0.05$.
In summary, S. caprea evidenced profound phytoremediation capacity on $\mathrm{Cd}$ and $\mathrm{Zn}$, although significant differences were noted among clones and treatments. Additionally, our results differed from the results of previous studies, wherein the interaction effects were synergistic with $\mathrm{Cd}$ in the presence of $\mathrm{Zn}$ but antagonistic with $\mathrm{Zn}$ in the presence of $\mathrm{Cd}$ in the combined $\mathrm{Cd}$ and $\mathrm{Zn}$ treatment group - this was attributed to the differences in clones and $\mathrm{Cd}$ and $\mathrm{Zn}$ concentrations in the soils. Nevertheless, among the complex interaction effects, we recommend S. caprea as an appropriate material for phytoremediation, and particularly clone BH3. However, further research will be required to assess the effects of $\mathrm{Cd}$ and $\mathrm{Zn}$ in terms of resultant physiological changes, in addition to their tolerance mechanisms against metal toxicity in clones of S. caprea.

\section{LITERATURE CITED}

Adriano DC. 1986. Trace Elements in the Terrestrial Environment. Springer-Verlag, New York, NY, pp 106-149.

Alloway BJ, Jackson AP, Morgan H. 1990. The accumulation of cadmium by vegetables grown on soils contaminated from a variety of sources. Sci Total Environ 91: 223-236.

Cakmak I, Welch RM, Erenoglu B, Römheld V, Norvell WA, Kochian LV. 2000. Influence of varied zinc supply on retranslocation of cadmium (109Cd) and rubidium (86Rb) applied on mature leaf of durum wheat seedlings. Plant Soil 219: 279-284.

Das P, Samantaray S, Rout GR. 1997. Studies on cadmium toxicity in plants: a review. Environ Pollut 98: 29-36.

Dickinson NM. 2000. Strategies for sustainable woodland on contaminated soils. Chemosphere 41: 259-263.

Dimitriou I, Eriksson J, Adler A, Aronsson P, Verwijst I. 2006. Fate of heavy metals after application of sewage sludge and wood-ash mixtures to short-rotation willow coppice. Environ Pollut 142: 160-169.

Dudka S, Piotrowska M, Chlopecka A. 1994. Effect of elevated concentrations of $\mathrm{Cd}$ and $\mathrm{Zn}$ in soil on spring wheat yield and the metal contents of the plants. Water Air Soil Pollut 76: 33-341.

Eriksson JE. 1990. A field study on factors influencing Cd levels in soils and in grain of oat and winter wheat. Water Air Soil Pollut 53: 69-81.

Gomes DS, Fragoso LC, Riger CJ, Panek AD, Eleutherio ECA. 2002. Regulation of cadmium uptake by Saccharomyces cerevisiae. Biochim Biophys Acta 1573: 21-25.

Han SH, Kim DH, Lee JC. 2007. Use of pioneer tree species to restore heavy metal-contaminated forest soil. Proceed- 
ings IUFRO Conference on Forest Landscape Restoration, 2007 May 14-17, Seoul, pp 220-221.

Hart JJ, Welch RM, Norvell WA, Kochian LV. 2002. Transport interactions between cadmium and zinc in roots of bread and durum wheat seedlings. Physiol Plant 116: 73-78.

Huebert DB, Shay JM. 1992. The effect of EDTA on cadmium and zinc uptake and toxicity in Lemna trisulca L. Arch Environ Contam Toxicol 22: 313-318.

Keller C, Hammer D, Kayser A, Richner W, Brodbeck M, Sennhauser M. 2003. Root development and heavy metal phytoextraction efficiency: comparison of different plant species in the field. Plant Soil 249: 67-81.

Klang-Westin E, Perttu K. 2002. Effects of nutrient supply and soil cadmium concentration on cadmium removal by willow. Biomass Bioenergy 23: 415-426.

Landberg T, Greger M. 2002. Interclonal variation of heavy metal interactions in Salix viminalis. Environ Toxicol Chem 21: 2669-2674.

Lewandowski I, Schmidt U, Londo M, Faaij A. 2006. The economic value of the phytoremediation function: assessed by the example of cadmium remediation by willow ( $S a$ lix ssp.). Agric Syst 89: 68-89.

Lunácková L, Masarovicová E, Král’ová K, Stresko V. 2003. Response of fast growing woody plants from family Salicaceae to cadmium treatment. Bull Environ Contam Toxicol 70: 576-585.

Meers E, Vandecasteele B, Ruttens A, Vangronsveld J, Tack FMG. 2007. Potential of five willow species (Salix spp.) for phytoextraction of heavy metals. Environ Exp Bot 60: 57-68.

Ministry of Environment. 2009. Soil Monitoring Networks and Results of Soil Pollution Monitor in 2008. Ministry of Environment, Gwacheon.

Moraghan JT. 1993. Accumulation of cadmium and selected elements in flax seed grown on a calcareous soil. Plant Soil 150: 61-68.

Nan Z, Li J, Zhang J, Cheng G. 2002. Cadmium and zinc interactions and their transfer in soil-crop system under actual field conditions. Sci Total Environ 285: 187-195.

Siedlecka A. 1995. Some aspects of interactions between heavy metals and plant mineral nutrients. Acta Soc Bot Pol 3: 265-272.
Smilde KW, Van Luit B, Van Driel W. 1992. The extraction by soil and absorption by plants of applied zinc and cadmium. Plant Soil 143: 233-238.

Tong YP, Kneer R, Zhu YG. 2004. Vacuolar compartmentalization: a second-generation approach to engineering plants for phytoremediation. Trends Plant Sci 9: 7-9.

Vandecasteele B, De Vos B, Tack FMG. 2002. Cadmium and zinc uptake by volunteer willow species and elder rooting in polluted dredged sediment disposal sites. Sci Total Environ 299: 191-205.

Vandecasteele B, Quataert P, De Vos B, Tack FMG, Muys B. 2004. Foliar concentrations of volunteer willows growing on polluted sediment-derived sites versus sites with baseline contamination levels. J Environ Monit 6: 313321.

Vandecasteele B, Meers E, Vervaeke P, De Vos B, Quataert P, Tack FMG. 2005. Growth and trace metal accumulation of two Salix clones on sediment-derived soils with increasing contamination levels. Chemosphere 58: 9951002.

Vervaeke P, Tack FMG, Navez F, Martin J, Verloo MG, Lust N. 2006. Fate of heavy metals during fixed bed downdraft gasification of willow wood harvested from contaminated sites. Biomass Bioenergy 30: 58-65.

White MC, Chaney RL. 1980. Zinc, cadmium, and manganese uptake by soybean from two zinc- and cadmiumamended coastal plain soils. Soil Sci Soc Am J 44: 308313.

Wu FB, Zhang GP. 2002. Alleviation of cadmium-toxicity by application of zinc and ascorbic acid in barley. J Plant Nutr 25: 2745-2761.

Xu W, Li W, He J, Singh B, Xiong Z. 2009. Effects of insoluble $\mathrm{Zn}, \mathrm{Cd}$, and EDTA on the growth, activities of antioxidant enzymes and uptake of $\mathrm{Zn}$ and Cd in Vetiveria $z i$ zanioides. J Environ Sci (China) 21: 186-192.

Xu WH, Wang HX, Liu H, Xiong ZT, Singh B. 2006. Effects of zinc, cadmium and their combined pollution on nutrient uptake and $\mathrm{Zn}$, Cd accumulation in ryegrass (Lofium perenne L.). Asian J Ecotoxicol 1: 70-74.

Zhou Q, Wu Y, Xiong X. 1994. Compound pollution of Cd and $\mathrm{Zn}$ and its ecological effect on rice plant. Chin J Appl Ecol 5: 428-441. (in Chinese) 